\title{
The Behavioral Profile of the Potent and Selective mGlu5 Receptor Antagonist 3-[(2-methyl- I,3-thiazol-4-yl)ethynyl] pyridine (MTEP) in Rodent Models of Anxiety
}

\author{
Chris S Busse*,', Jesse Brodkin', David Tattersall', Jeffery J Anderson', Noelle Warren', Lida Tehrani', \\ Linda J Bristow', Mark A Varney' and Nicholas DP Cosford' \\ 'Merck Research Laboratories, San Diego, CA, USA
}

\begin{abstract}
Previous reports have demonstrated the anxiolytic effect of the potent and systemically active metabotropic glutamate subtype 5 (mGlu5) receptor antagonist 2-methyl-6-(phenylethynyl)pyridine (MPEP) in rodents. Here, we present evidence for the anxiolytic activity of a novel mGlu5 receptor antagonist, 3-[(2-methyl-1,3-thiazol-4-yl)ethynyl]pyridine (MTEP), in rats and compare its profile to the benzodiazepine receptor agonist diazepam. MTEP occupied $m$ Glu5 receptors in a dose-dependent manner with essentially full receptor occupancy at the highest dose tested ( $10 \mathrm{mg} / \mathrm{kg}$, i.p.). At doses appropriate for mGlu5 receptor-mediated effects, MTEP significantly reduced fear-potentiated startle and increased punished responding in a modified Geller-Seifter conflict model consistent with an anxiolytic-like profile. In both models, the magnitude of the anxiolytic-like response was similar to that seen with diazepam. In contrast, MTEP decreased unpunished responding to a lesser extent than diazepam and had no effect on rotarod performance when administered either alone or in combination with ethanol. Repeated dosing with MTEP in this model eliminated the increase in punished responding observed with acute dosing. The present results suggest that $\mathrm{mGlu} 5$ receptor antagonists lack the side effects seen with benzodiazepines, such as sedation and ethanol interaction, and provide insight into a possible role for mGlu5 receptor antagonists in the modulation of mood disorders.

Neuropsychopharmacology (2004) 29, 197|-1979, advance online publication, I I August 2004; doi: I0. 1038/sj.npp. I 300540
\end{abstract}

Keywords: anxiety; metabotropic glutamate receptor 5; MTEP; tolerance

\section{INTRODUCTION}

Glutamate is the principle excitatory transmitter in the central nervous system and mediates fast excitatory transmission through interactions with inotropic glutamate receptors (NMDA, AMPA, and kainate receptors). In addition, glutamate may also exert a more modulatory influence over synaptic transmission through activation of G-protein-coupled metabotropic glutamate (mGlu) receptors which have a presynaptic, postsynaptic, or perisynaptic localization (Baude et al, 1993; Petralia et al, 1996; Shigemoto et al, 1997). To date, eight mGlu receptors have been cloned and functionally expressed. These have been classified into three groups based on amino-acid sequence homology, functional coupling, and pharmacology (Conn and Pin, 1997). The Group I family includes mGlul and

\footnotetext{
*Correspondence: CS Busse, Merck Research Laboratories, 3535 General Atomics Court, San Diego, CA 92121, USA,

E-mail: Christopher_busse@merck.com

Received 24 October 2004; revised 6 July 2004; accepted 6 July 2004 Online publication: 13 July 2004 at http://www.acnp.org/citations/ Npp07/30403489/default.pdf
}

mGlu5 receptors; activation of these receptors stimulates phospholipase $\mathrm{C}$, resulting in phosphoinositide hydrolysis and elevation of intracellular $\mathrm{Ca}^{2+}$ levels. Group I mGlu receptors have also been shown to modulate ion channels such as $\mathrm{K}^{+}$channels (Ikeda et al, 1995; Levy et al, 1998), $\mathrm{Ca}^{2+}$ channels (Takahashi et al, 1996; McCool et al, 1998), and nonselective cation channels (Zhou and Hablitz, 1997).

The specific localization and expression pattern of mGlu5 receptors in the rodent forebrain suggests an involvement in emotional and motivational processes (Shigemoto et al, 1993; Romano et al, 1995). Investigation of the therapeutic relevance of mGlu5 receptor has progressed with the development of selective, noncompetitive antagonists such as SIB-1757, SIB-1893, and 2-methyl-6-(phenylethynyl)pyridine (MPEP) (Varney et al, 1999; Gasparini et al, 1999). The potent and systemically active mGlu5 receptor antagonist MPEP has been shown to exhibit anxiolytic-like effects in a variety of conditioned and unconditioned rodent models of anxiety (Spooren et al, 2000, 2002; Tatarczynska et al, 2001; Brodkin et al, 2002a). In addition, the lack of an anxiolytic effect of an mGlu5 receptor antagonist in mGlu5 ${ }^{-1-}$ mice and the observed anxiolytic-like phenotype of these mice supports the suggestion that blockade of 
mGlu5 receptors in vivo causes a reduction in anxietyrelated behaviors (Brodkin et al, 2002b). Taken together, these data strongly suggest the potential therapeutic utility of selective mGlu5 receptor antagonists for the treatment of anxiety in humans.

While the prototypical mGlu5 receptor antagonist MPEP has high potency $(\mathrm{Ki}=12 \mathrm{nM})$, it also has several drawbacks including significant off-target activity and a high $\log D$ leading to poor solubility in CSF (Cosford et al, 2003b; Mathiesen et al, 2003). These limitations of MPEP led us to design and synthesize the mGlu5 receptor antagonist 3-[(2methyl-1,3-thiazol-4-yl)ethynyl]pyridine (MTEP) (Figure 1) which retains the in vitro potency of MPEP $(\mathrm{Ki}=16 \mathrm{nM})$, but has superior selectivity and reduced off-target liabilities (Cosford et al, 2003b). In the present study, we have examined the effects of MTEP in two conditioned models of anxiety and compared its efficacy with the benzodiazepine receptor agonist diazepam. Since anxiety often requires long-term pharmacological treatment, we also examined the efficacy of MTEP following chronic dosing in the conflict model. The results suggest that MTEP exhibits comparable anxiolytic-like effects without disrupting motor performance or potentiating the motor disruption induced by ethanol, providing further insight into a potential role for mGlu5 receptor antagonists in the treatment of anxiety.

\section{METHODS}

\section{In Vivo Pharmacology}

All procedures involving animals were approved by the Institutional Animal Care and Use Committee in accordance with 'The Guide for the Care and Use of Laboratory Animals.'

\section{In Vivo Receptor Occupancy}

In vivo receptor occupancy of MTEP was determined using methods described previously (Anderson et al, 2002). In brief, rats were dosed i.p. with MTEP dissolved in $10 \% \mathrm{v} / \mathrm{v}$ Tween-80:90\% water ( $2 \mathrm{ml} / \mathrm{kg}$ injection volume). At $1 \mathrm{~min}$ prior to tissue collection, $\left[{ }^{3} \mathrm{H}\right]$-methoxy-PEPy (Cosford et al, 2003a) was administered $(30 \mu \mathrm{Ci} / \mathrm{kg})$ through a lateral tail vein. Animals were then euthanized and the hippocampus was rapidly dissected on a cooled dissecting tray. The hippocampus was immediately weighed and homogenized in $10 \mathrm{v}$ of ice-cold buffer $(10 \mathrm{mM}$ potassium phosphate, $100 \mathrm{mM} \mathrm{KCl}, \mathrm{pH}$ 7.4) using a Polytron. Homogenates

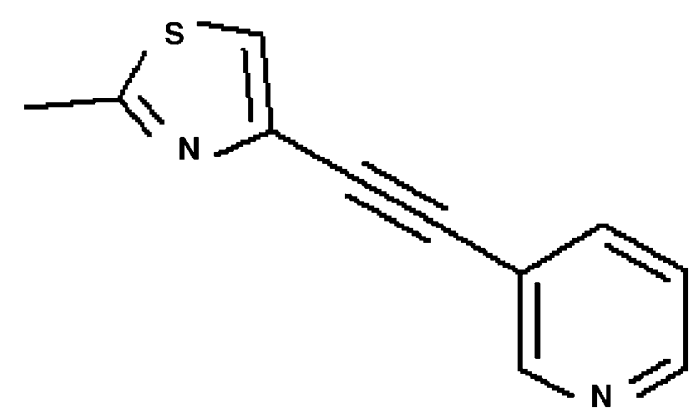

Figure I Structure of MTEP.
$(400 \mu \mathrm{l})$ were then filtered over GF/B membrane filters (Whatman) and washed twice with $5 \mathrm{ml}$ ice-cold homogenization buffer to separate bound from free radioactivity. Filters were then counted for radioactivity using a Beckman counter. Nonspecific binding of $\left[{ }^{3} \mathrm{H}\right]$-methoxy-PEPy was estimated by measuring radioactivity in washed filters following administration of $50 \mathrm{mg} / \mathrm{kg}$ MPEP i.p.

\section{Fear-Potentiated Startle (FPS) Model}

Adult experimentally naïve male Wistar rats (Charles River, 225-300 g) were used for FPS studies as described previously (Brodkin et al, 2002a). Animals were housed in groups of three and allowed free access to food and water. The housing room was temperature- and humidity-controlled, with a 12-h light/dark cycle (lights on at $0630 \mathrm{~h}$ ).

Training. Animals were trained to associate light with foot shock for 2 days prior to testing. On each training day, animals were placed into the startle apparatus (SR-LAB, San Diego Instruments, San Diego, CA) and exposed to 30 light (4 W bulb; $10 \mathrm{~s}$ duration) + foot shock (0.6 mA; $500 \mathrm{~ms})$ pairings delivered at $1 \mathrm{~min}$ intervals. Foot shocks were delivered during the last $500 \mathrm{~ms}$ of the light stimulus.

Testing. After 2 consecutive days of training, animals were administered drug or vehicle prior to being placed into the startle apparatus. Diazepam $(0.3,1$ or $3 \mathrm{mg} / \mathrm{kg}$, s.c.; $1 \mathrm{ml} / \mathrm{kg})$ was administered in $10 \% \mathrm{v} / \mathrm{v}$ Tween $80: 90 \%$ water $30 \mathrm{~min}$ prior to testing. MTEP $(0.3,1$ or $3 \mathrm{mg} / \mathrm{kg}$, i.p.; $1 \mathrm{ml} / \mathrm{kg})$ was administered in $10 \% \mathrm{v} / \mathrm{v}$ Tween $80: 90 \%$ water $60 \mathrm{~min}$ prior to testing. The testing procedure consisted of 42 presentations of an acoustic stimulus $(95 \mathrm{~dB}, 20 \mathrm{~ms})$ presented $30 \mathrm{~s}$ apart. A pseudo-random sequence was used to present one half of the acoustic stimuli preceded by $10 \mathrm{~s}$ of the $4 \mathrm{~W}$ light. The animals received no shocks on the test day. Force transducers located under the animals in the apparatus collected data from the acoustic startle response and expressed the data in constant arbitrary units (units were based on calibration with standard equipment). The data were then separated for each animal into responses made in the presence of the light and those made in the dark (21 light, 21 dark) and expressed as the mean response for each animal.

\section{Geller-Seifter Model}

Adult male Sprague-Dawley rats (Harlan, 290-330 g) were used as described previously (Brodkin et al, 2002a). Rats were food restricted to $85 \%$ of their free-feeding body weight. Animals were fed $2 \mathrm{~h}$ after completion of the training or testing session to maintain them at $85 \%$ of their free-feeding body weight. Animals were individually housed with free access to water.

Training. Animals were placed into a standard operant chamber (ENV-018M, Med Associates, St Albans, VT) equipped with a lever, house light, speaker, food dispenser, and a grid floor through which a shock could be delivered from a programmable shocker. Animals were trained to press the lever, while the house light was on for a food 
reward pellet ( $45 \mathrm{mg}$, BioServ, Frenchtown, NJ) during a $30 \mathrm{~min}$ session. The number of lever presses required to obtain a food pellet reward was gradually increased until the animals had obtained a stable rate of pressing 30 times for one pellet delivery (FR-30). Once this stable rate of responding was achieved during the unpunished component, a second component was introduced in which each FR-30 produced a food pellet accompanied by a foot shock (0.50-0.80 mA for $500 \mathrm{~ms})$. This punished component was signaled by an $80-\mathrm{dB}$ tone in addition to the house light. The shock level was adjusted for each animal until a ratio of $5: 1$ for the rate of responding in unpunished $v s$ rate of responding in punished was attained. Once stable rates of responding had been established in the unpunished and the punished components, the animals were switched to the testing schedule. Training required approximately 3-4 months. The testing schedule consisted of unpunished and punished components, separated by a time-out component. Each component lasted for $5 \mathrm{~min}$. There was no light or tone and no consequence for responses during the time out. This three-component cycle was repeated twice per session.

Testing. Animals were tested once they had achieved stable baseline rates of responding for 5 days (no significant trend up or down). Animals were run on the testing procedure Monday-Friday, with drug or vehicle treatments administered on Tuesday and Friday. Animals displaying abnormal rates of responding on nontreatment days (ie $>20 \%$ change from the animal's normal baseline) were excluded from drug testing until normal responding returned for three consecutive sessions. For acute studies, diazepam $(0.3,1$ or $1.7 \mathrm{mg} / \mathrm{kg}$, s.c.; $1 \mathrm{ml} / \mathrm{kg}$ ) was administered in $10 \% \mathrm{v} / \mathrm{v}$ Tween $80: 90 \%$ water $30 \mathrm{~min}$ prior to testing. MTEP $(1,3$ or $10 \mathrm{mg} /$ $\mathrm{kg}$, i.p.; $1 \mathrm{ml} / \mathrm{kg}$ ) was administered in $10 \% \mathrm{v} / \mathrm{v}$ Tween $80: 90 \%$ water $60 \mathrm{~min}$ prior to testing. For chronic studies, animals were dosed with vehicle $10 \% \mathrm{v} / \mathrm{v}$ Tween $80: 90 \%$ water $60 \mathrm{~min}$ prior to testing on day 1 . MTEP $(3 \mathrm{mg} / \mathrm{kg}$, i.p.; $1 \mathrm{ml} / \mathrm{kg}$ ) was administered $60 \mathrm{~min}$ prior to testing on day 2 and immediately after testing on days 3 and 4 at the same dose. On day 5, MTEP ( $3 \mathrm{mg} / \mathrm{kg}$, i.p.; $1 \mathrm{ml} / \mathrm{kg}$ ) was again administered 60 min prior to testing. Data were collected as rates of responding (responses per second) from the unpunished and the punished components and expressed as an average over the entire session.

\section{Rotarod Performance and Ethanol Interaction Studies}

Rotarod studies were carried out in male Swiss Webster mice (Harlan, Indianapolis, IN, 22-29 g). Animals were housed in groups of 4 and maintained on a $12 \mathrm{~h}$ light: dark schedule (lights on at $0630 \mathrm{~h}$ ) in a temperature- and humidity-controlled room with food and water freely available. Prior to dosing, all mice were placed on a rotarod revolving at $12 \mathrm{rpm}$ and trained to remain on the apparatus for $120 \mathrm{~s}$. To examine the effects of MTEP, mice were dosed with either vehicle $(10 \% \mathrm{v} / \mathrm{v}$ Tween 80 in saline; $5 \mathrm{ml} / \mathrm{kg}$, s.c.) or MTEP (3-30 mg/kg, s.c.) and the latency to fall from the rotarod was determined at various time points later. Similar time course studies were also conducted in mice dosed with diazepam (1-30 mg/kg, p.o.), ethanol (1-3 g/kg, i.p.) or appropriate vehicles $(5 \% \mathrm{v} / \mathrm{v}$ Tween 80 in water ( $5 \mathrm{ml} / \mathrm{kg}$, p.o.) or saline $(10 \mathrm{ml} / \mathrm{kg}$, i.p.), respectively) were tested at $30 \mathrm{~min}$ after treatment. To examine interactions with ethanol, mice were pretreated with either vehicle (saline; $10 \mathrm{ml} / \mathrm{kg}$, i.p.) or a submaximal dose of ethanol ( $1.5 \mathrm{~g} / \mathrm{kg}$, i.p.) $15 \mathrm{~min}$ prior to administration of MTEP $(30 \mathrm{mg} / \mathrm{kg}$, s.c.) or vehicle $(10 \% \mathrm{v} / \mathrm{v}$ Tween 80 in water; $5 \mathrm{ml} /$ $\mathrm{kg}$, s.c.). Animals were then tested for their ability to remain on the rotarod $15 \mathrm{~min}$ later and the latency to fall recorded (maximum cutoff time $=120 \mathrm{~s}$ ). For comparison, separate groups of mice were treated with diazepam $(3 \mathrm{mg} / \mathrm{kg}$, p.o.) alone or received combined diazepam $(3 \mathrm{mg} / \mathrm{kg}$, p.o. $)+$ ethanol (1.5 g/kg, i.p.) treatment and were tested for rotarod performance $30 \mathrm{~min}$ later.

In vivo receptor occupancy was determined immediately after rotarod testing. Thus, selected mice were injected via a lateral tail vein with $\left[{ }^{3} \mathrm{H}\right]$-methoxy-PEPy $(30 \mu \mathrm{Ci} / \mathrm{kg} ; 5 \mathrm{ml} / \mathrm{kg}$ injection volume in saline). After $1 \mathrm{~min}$, mice were euthanized and the right forebrain was rapidly dissected, homogenized, and filtered as described above for rats. Nonspecific binding of $\left[{ }^{3} \mathrm{H}\right]$-methoxy-PEPy in mice was estimated by measuring radioactivity in washed filters $5 \mathrm{~min}$ following administration of a saturating dose of MPEP (50 mg/kg, i.p.). To determine plasma ethanol concentrations, trunk blood was collected into heparinized tubes and spun at $8000 \mathrm{~g}$ to obtain plasma. Ethanol concentrations in terminal plasma samples were estimated from alcohol dehydrogenase activity (Sigma).

\section{MATERIALS}

Diazepam (Elkins-Sinn, Cherry Hill, NJ) was diluted in $10 \%$ v/v Tween 80:90\% water. Ethanol (Sigma, St Louis, MO) was diluted in saline. All other compounds, including MPEP, MTEP, and $\left[{ }^{3} \mathrm{H}\right]$-methoxy-PEPy, were synthesized at Merck Research Laboratories (San Diego and Rahway, NJ). For occupancy and behavioral studies, MTEP was dissolved in 10\% v/v Tween $80: 90 \%$ water and administered i.p. To define nonspecific binding in vivo, MPEP was administered i.p. in $50 \%$ PEG400 $(2 \mathrm{ml} / \mathrm{kg})$.

\section{Data Analysis and Statistics}

The percent receptor occupancy was calculated by first expressing the specific binding value from each animal as a percentage of specific binding of the vehicle group, then subtracting that value from 100 (ie \% occupancy $=100-\%$ vehicle binding). Nonlinear regression analysis (Graphpad Prism, San Diego, CA) was used to calculate the dose of MTEP which occupies $50 \%$ of the receptors $\left(\mathrm{ED}_{50}\right)$. Differences in receptor occupancy between dosing groups and vehicle were determined by analysis of variance and Dunnett's $t$-test. Data collected from FPS sessions were analyzed using two-way repeated-measures ANOVA with Student-Newman-Keuls post hoc comparison procedure. $\mathrm{ED}_{50}$ values were calculated by taking the difference scores between the startle amplitude in the light minus the startle amplitude in the dark and interpolating a dose which reduced the difference to $50 \%$ of that observed in the vehicle control group. Data from Geller-Seifter sessions were divided into the separate unpunished and punished components due to the bimodal distribution of the data from each session. Data from each component were 
analyzed using a one-way repeated-measures ANOVA, followed by Student-Newman-Keuls post hoc multiple comparison procedure. Data from rotarod studies were analyzed by one-way or two-way repeated-measures ANOVA, followed by Dunnett's $t$-test or Tukey's multiple post hoc comparisons.

\section{RESULTS}

\section{In Vivo Receptor Occupancy}

MTEP produced marked occupancy of mGlu5 receptors in the hippocampus following systemic dosing in rats (Figure 2). The ability of MTEP to occupy mGlu5 receptors was dose-dependent and at $1 \mathrm{~h}$ post-administration the dose required to occupy $50 \%$ of mGlu5 receptors $\left(\mathrm{ED}_{50}\right)$ was $1.2 \mathrm{mg} / \mathrm{kg}$. Essentially full receptor occupancy $(98 \pm 3 \%)$ was achieved with the $10 \mathrm{mg} / \mathrm{kg}$ dose of MTEP.

\section{Effect of MTEP and Diazepam in the FPS Model}

A significant difference between the response in the light between the vehicle-treated animals and the drug-treated animals was observed with diazepam and MTEP, indicative of an anxiolytic effect. At the dose of $3 \mathrm{mg} / \mathrm{kg}$, diazepam significantly decreased the startle amplitude in the light $v s$ vehicle $(P<0.05$; Figure $3 \mathrm{a})$. The startle amplitude in the presence of the light was significantly larger $(P<0.05)$ than the startle amplitude in the dark in animals treated with vehicle, 0.3 and $1 \mathrm{mg} / \mathrm{kg}$ (but not $3 \mathrm{mg} / \mathrm{kg}$ ) diazepam. At doses of 1 and $3 \mathrm{mg} / \mathrm{kg}$, MTEP significantly decreased the startle amplitude in the light $v s$ vehicle $(P<0.05$; Figure $3 \mathrm{~b})$. The startle amplitude in the presence of the light was significantly larger $(P<0.05)$ than the startle amplitude in the dark in animals treated with vehicle, 0.3 and $1 \mathrm{mg} / \mathrm{kg}$ (but not $3 \mathrm{mg} / \mathrm{kg}$ ) MTEP. The potencies of MTEP and diazepam in decreasing the potentiation of startle were similar, with $\mathrm{ED}_{50}$ values of 0.7 and $0.9 \mathrm{mg} / \mathrm{kg}$, respectively.

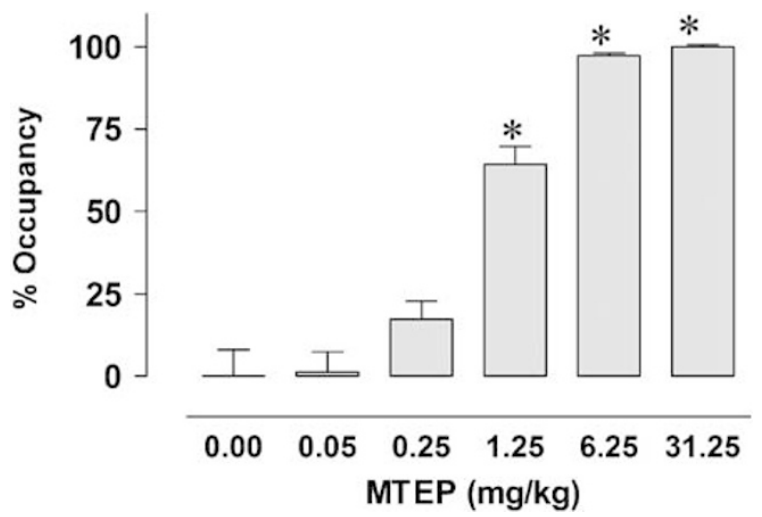

Figure 2 Occupancy of mGlu5 receptors following systemic administration of vehicle or MTEP in rats. Receptor occupancy in hippocampus was assessed I h following i.p. administration of MTEP and $\left[{ }^{3} \mathrm{H}\right]$-methoxy-PEPy $(30 \mu \mathrm{Ci} / \mathrm{kg}$, i.v.) was used for labeling mGlu5 receptors (administered I min prior to tissue collection). Hippocampal tissue was dissected, homogenized, and filtered. Specific binding values were expressed as a percent of vehicle and subtracted from 100 to obtain \% occupancy values. The values represent the mean \pm SEM ( $n=3-4$ rats/group). ${ }^{*} P<0.05$ versus vehicle by analysis of variance and Dunnett's t-test.

\section{Effect of MTEP and Diazepam in the Geller-Seifter Conflict Model}

Acute studies. Both MTEP and diazepam caused a significant dose-dependent increase in the rate of punished responding compared to vehicle (Figure $5 \mathrm{a}$ and $\mathrm{b}$ ). MTEP increased the rate of punished responding at $3 \mathrm{mg} / \mathrm{kg}$ $(P<0.05)$ and at $10 \mathrm{mg} / \mathrm{kg}(P<0.01)$. Diazepam increased the rate of punished responding at $0.3 \mathrm{mg} / \mathrm{kg}(P<0.01)$, $1 \mathrm{mg} / \mathrm{kg}(P<0.01)$, and $1.7 \mathrm{mg} / \mathrm{kg}(P<0.05)$. Diazepam was not administered at $3 \mathrm{mg} / \mathrm{kg}$ as in the potentiated startle study, since it produced a near-complete suppression of responding in both the unpunished and punished components (data not shown). Diazepam significantly decreased the rate of unpunished responding at $1.7 \mathrm{mg} / \mathrm{kg}(P<0.01)$ (Figure 4a). MTEP also significantly decreased the rate of unpunished responding at $10 \mathrm{mg} / \mathrm{kg}$, the highest dose tested $(P<0.01)$ (Figure $4 \mathrm{~b})$, although the effect was less marked than that seen with diazepam (Figures 4 and 5).

Chronic studies. MTEP increased the rate of punished responding at $3 \mathrm{mg} / \mathrm{kg}(P<0.05)$ on day 2 , the first day of

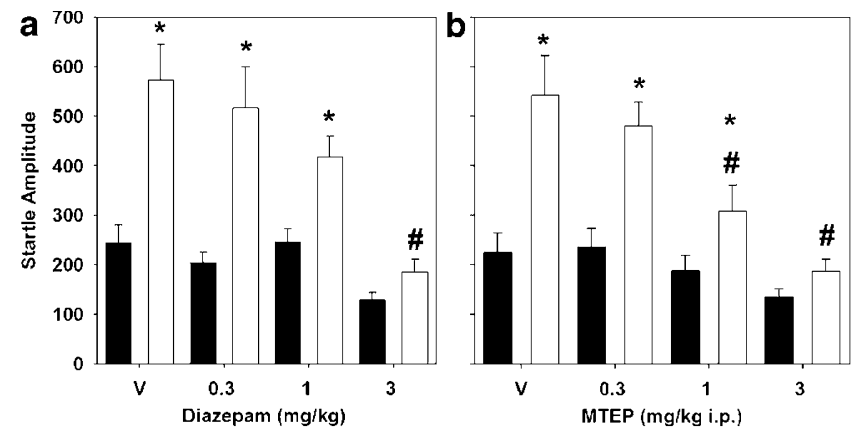

Figure 3 The effect of diazepam (a) and MTEP (b) on FPS. Closed bars represent the mean startle amplitude in the dark and open bars represent the mean startle amplitude in the light $\pm \operatorname{SEM}(n=8$ Wistar rats per bar set). $* P<0.05$ compared within the dose group to startle amplitude in the dark. ${ }^{\#} P<0.05$ compared to the vehicle control group startle in the light.
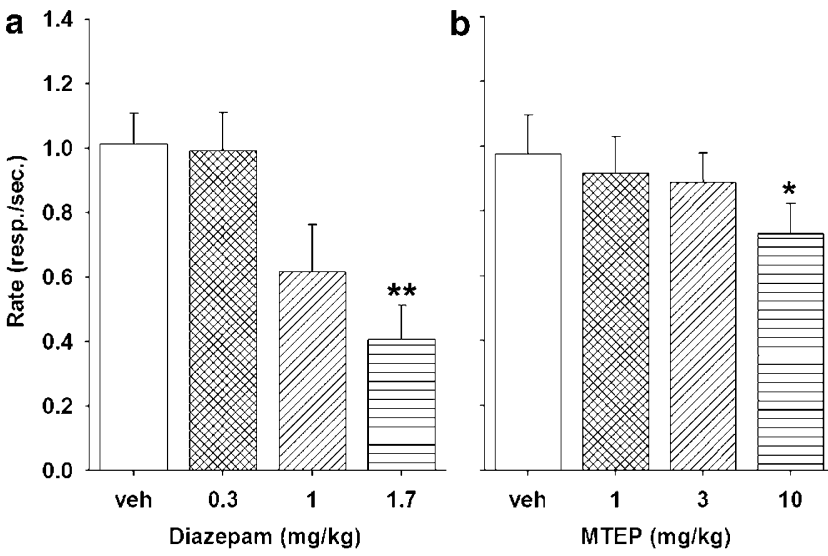

Figure 4 The effect of diazepam (a) and MTEP (b) on unpunished responding in the Geller-Seifter assay. Bars represent the mean rate of responding \pm SEM recorded over the entire session $(n=12$ SpragueDawley rats per dose-effect curve). $* P<0.01$ or $* * P<0.00$ I compared to within-subject vehicle control. 
administration. On day 5 , following 3 days of administration of MTEP at $3 \mathrm{mg} / \mathrm{kg}$, MTEP did not significantly increase the rate of punished responding when administered at $3 \mathrm{mg} / \mathrm{kg}$ prior to the session. The rate of punished responding on day 5 was significantly reduced compared to day $2(P<0.05)$. There was no effect on punished responding on days 3 and 4 , nor was there any effect on unpunished responding during the chronic studies.
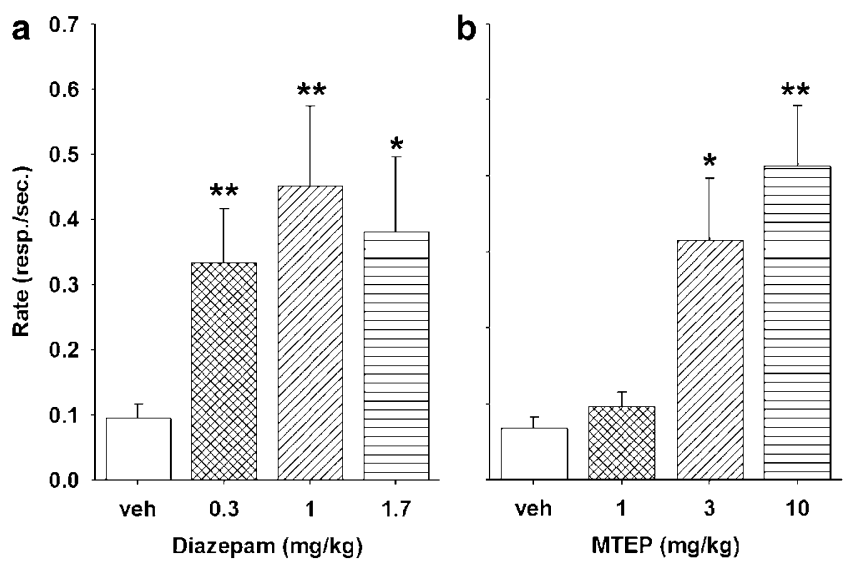

Figure 5 The effect of diazepam (a) and MTEP (b) on punished responding in the Geller-Seifter assay. Bars represent mean rate of responding \pm SEM recorded over the entire session $(n=12$ SpragueDawley rats per dose-effect curve). ${ }^{*} P<0.05$ or ${ }^{*} * P<0.01$ compared to within-subject vehicle control.

\section{Effect of MTEP and Diazepam on Rotarod Performance and Potential for Ethanol Interactions in Mice}

To examine the effects of MTEP on motor coordination, mice were pre-trained to remain on a rotarod revolving at $12 \mathrm{rpm}$ for $120 \mathrm{~s}$, after which rotarod performance was re-assessed at various time points after dosing. For comparison, the effects of diazepam and ethanol were also examined. As expected, oral administration of diazepam dose-dependently impaired performance with significant reductions in time spent on the rotarod seen $30 \mathrm{~min}$ after dosing with 10 and $30 \mathrm{mg} / \mathrm{kg}$ (Table 1). At the highest dose tested $(30 \mathrm{mg} / \mathrm{kg}$, p.o.), the deficits in rotarod performance were profound and long lasting, with significant effects still apparent up to 120 min later. A significant reduction in time spent on the rotarod was also observed in the first $30 \mathrm{~min}$ after dosing with $3000 \mathrm{mg} / \mathrm{kg}$ (i.p.) ethanol in mice (Table 1). In contrast, pretreatment with MTEP had no effect on rotarod performance at the doses tested (Table 1).

To examine potential interactions with ethanol, mice were dosed with a subthreshold dose of $1500 \mathrm{mg} / \mathrm{kg}$ (i.p.) ethanol, $15 \mathrm{~min}$ prior to MTEP $(30 \mathrm{mg} / \mathrm{kg}$, s.c.) and then tested for rotarod performance $15 \mathrm{~min}$ later (ie $30 \mathrm{~min}$ post-ethanol). For comparison, separate groups of mice received either a subthreshold dose of diazepam $(3 \mathrm{mg} / \mathrm{kg}$, p.o.) or combined treatment with diazepam $(3 \mathrm{mg} / \mathrm{kg}$, p.o.) + ethanol $(1500 \mathrm{mg} / \mathrm{kg}$, i.p.) $30 \mathrm{~min}$ prior to testing. As expected, combined treatment with diazepam + ethanol produced a marked reduction in time spent on the rotarod, which was greater than the sum of the effects of either

Table I Mice were Trained to Remain on a Rotarod Revolving at $12 \mathrm{rpm}$ for $120 \mathrm{~s}$, After which They were Dosed with Either Vehicle or Test Compound and Retested at Various Time Points. Results are Expressed as the Mean \pm SEM Latency (s) to Fall from the Rotarod ( $n=7-8$ mice/group). Data were Analyzed by Two-way Repeated-Measures Analysis of Variance, Followed by One-way Analysis of Variance with Dennett's t-Test at Each Time Point; $* P<0.05$ Compared to Vehicle-Treated Mice

Latency to fall from Rotarod (s)

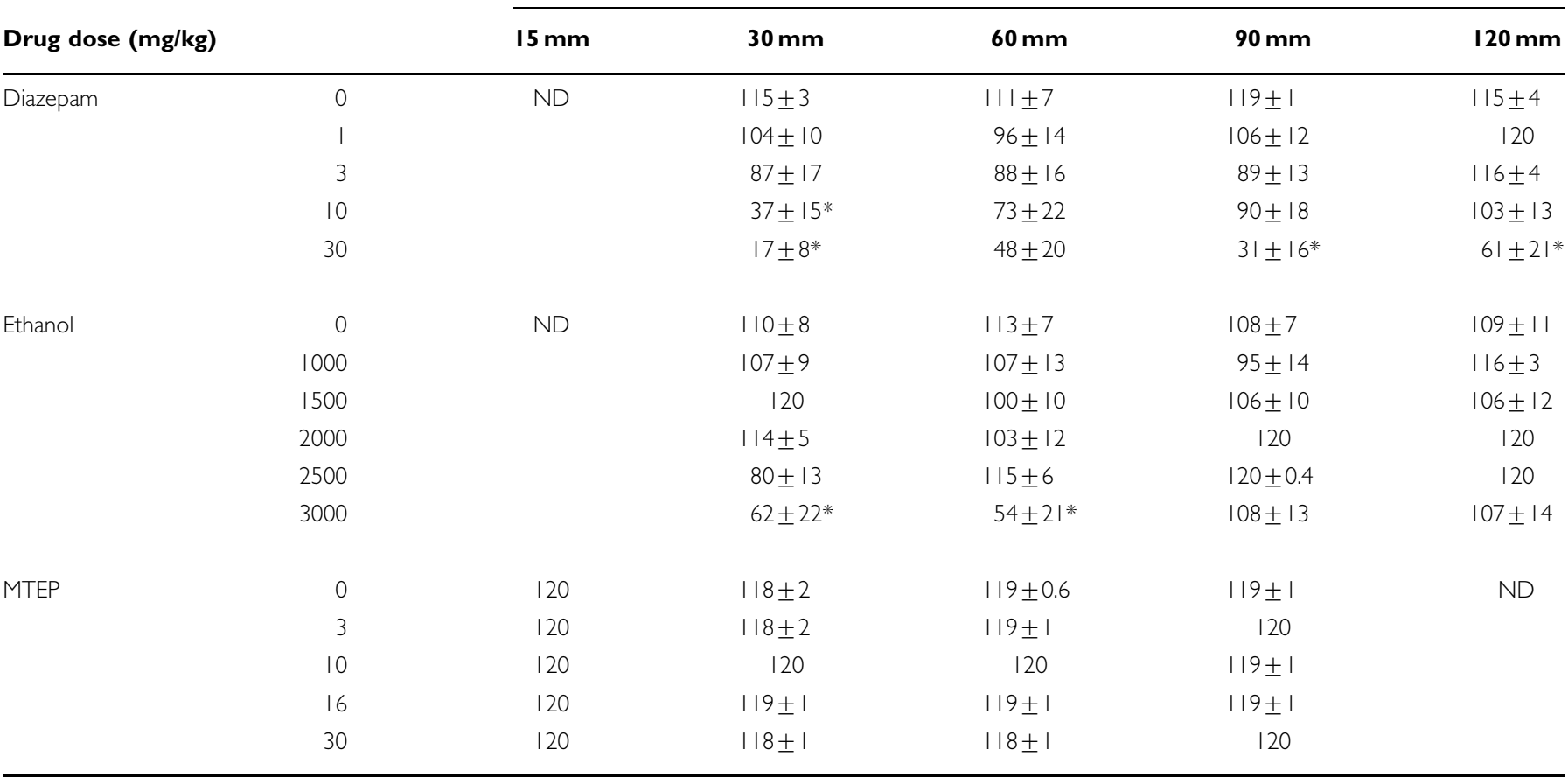



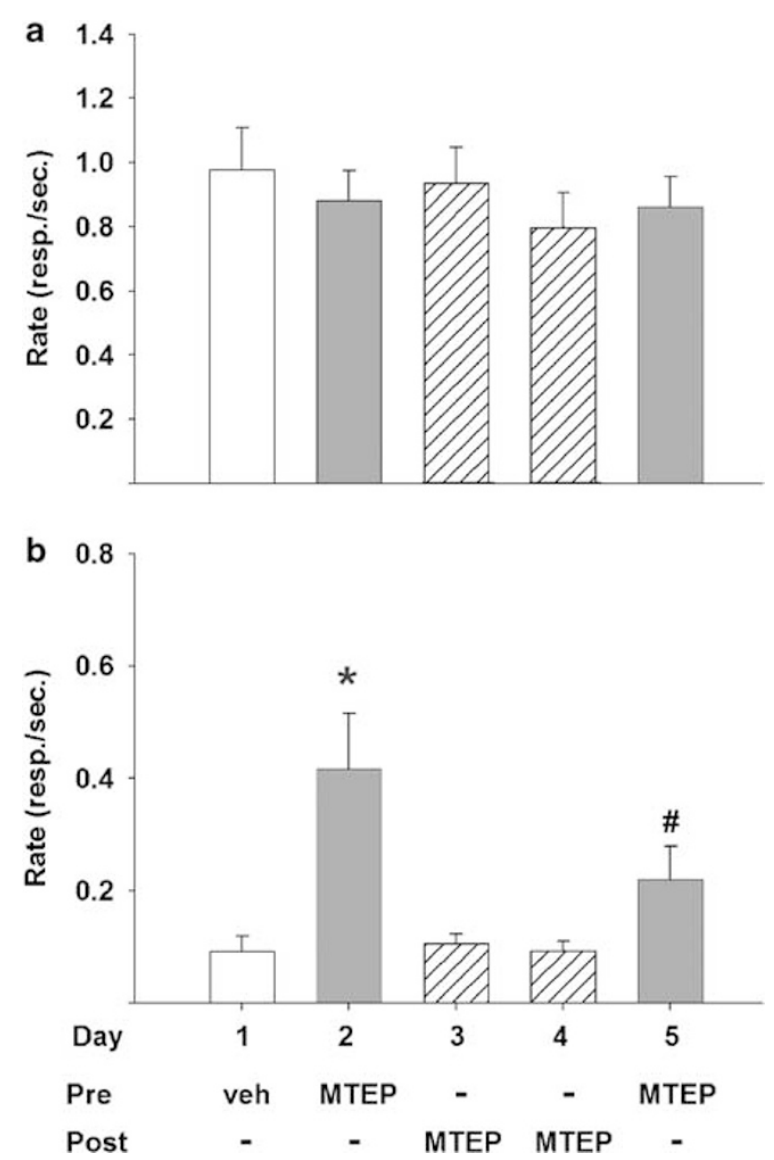

Figure 6 The effect of chronic MTEP (3 mg/ $\mathrm{kg}$, i.p.) treatment on (a) unpunished and (b) punished responding in the Geller-Seifter assay. Bars represent mean rate of responding \pm SEM recorded over the entire session $(n=14$ Sprague-Dawley rats). $* P<0.05$ compared to vehicle control on day I; ${ }^{\#} P<0.05$ compared to MTEP pretreatment on day 2 .

treatment alone (Figure 7a). In contrast, treatment with MTEP per se or combined treatment with ethanol + MTEP had no effect on rotarod performance (Figure 6a).

On completion of behavioral testing, selected mice were dosed i.v. with $\left[{ }^{3} \mathrm{H}\right]$-methoxy-PEPy to determine in vivo receptor occupancy. Nonspecific binding (ie 100\% receptor occupancy) was determined in a separate group of mice dosed with MPEP ( $50 \mathrm{mg} / \mathrm{kg}$, i.p.) $4 \mathrm{~min}$ prior to injection of the radiolabel. At the dose of $30 \mathrm{mg} / \mathrm{kg}$ (s.c.), MTEP fully occupied forebrain mGlu5 receptors and occupancy was similar in both vehicle + MTEP- or ethanol + MTEP-treated mice (Figure $7 \mathrm{~b}$ ). In addition, plasma ethanol concentrations were identical $(0.08 \%)$ in ethanol/vehicle- and ethanol/ MTEP- $(30 \mathrm{mg} / \mathrm{kg})$ treated animals, indicating that MTEP had no effect on ethanol metabolism (data not shown).

\section{DISCUSSION}

The need for novel therapeutic agents for the treatment of anxiety is well documented (for reviews, see Argyropoulos et al, 2000; Lydiard, 2000). Anxiety disorders are the most prevalent form of psychiatric disorders in the United States, exacting a significant financial and emotional toll on society (DuPont et al, 1996). a
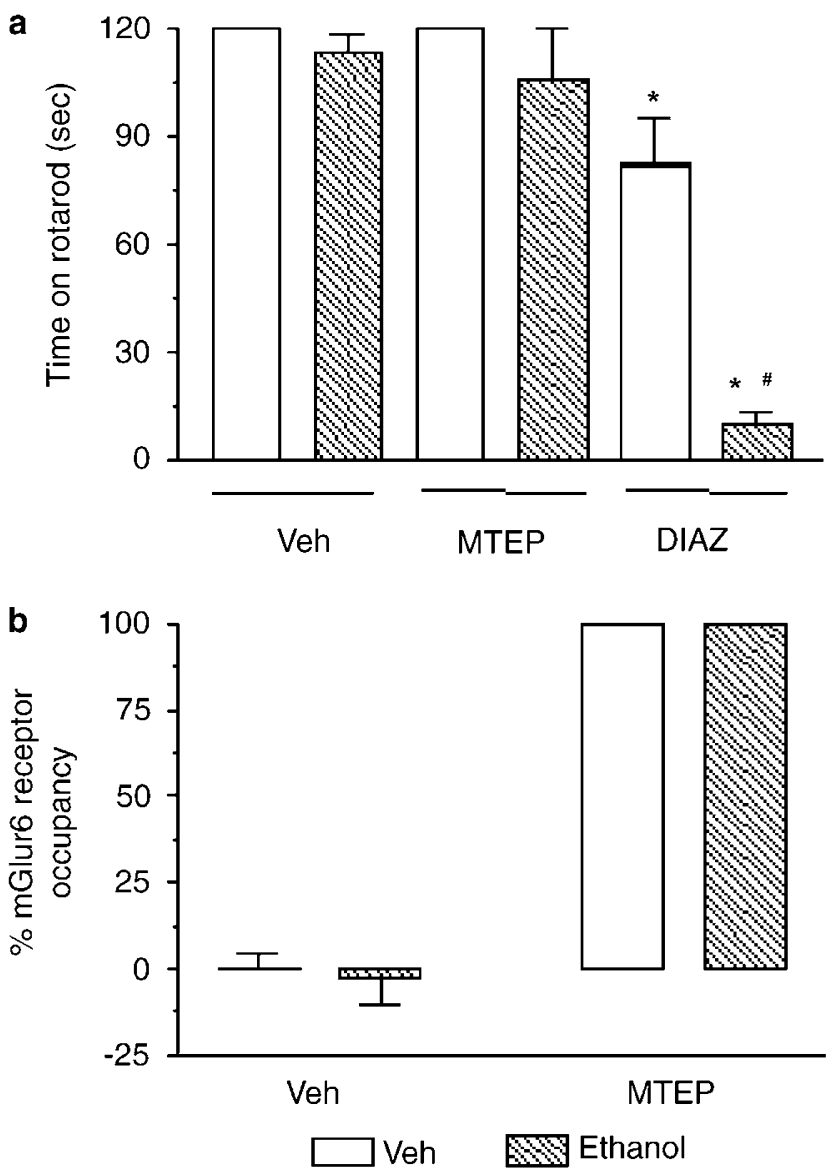

Figure 7 (a) Potentiation of ethanol effects on rotarod performance in mice treated with MTEP or diazepam. Animals were dosed with either vehicle (Veh; open bars) or ethanol (I500 mg/kg, i.p.; hatched bars) $15 \mathrm{~min}$ prior to vehicle (Veh) or MTEP (30 mg/kg, s.c.) and tested on the rotarod $15 \mathrm{~min}$ later. For comparison, separate animals received diazepam (DIAZ; $3 \mathrm{mg} / \mathrm{kg}$, p.o.) + vehicle (open bars) or diazepam + ethanol (hatched bars) 30 min prior to testing. Results are expressed as the mean \pm SEM latency $(\mathrm{s})$ to fall from the rotarod ( $n=7-8 /$ group). Data were analyzed by one-way analysis of variance followed by Tukey's $t$-test; $* P<0.05$ compared to vehicle + vehicle-treated mice; ${ }^{\#} P<0.05$ compared to vehicle + diazepamtreated mice. (b) In vivo mGlu5 receptor occupancy in mice. Immediately after testing on the rotarod selected mice ( $n=5-6 /$ group) were dosed i.v. with $\left[{ }^{3} \mathrm{H}\right]$-methoxy-PEPy. Nonspecific binding was defined in mice dosed with $50 \mathrm{mg} / \mathrm{kg}$, i.p., MPEP $(n=2)$. Results are expressed as the mean $\% \pm$ SEM mGlu5 receptor occupancy in mouse forebrain.

Current pharmacological treatment strategies usually involve the use of benzodiazepines, serotonin reuptake inhibitors (SSRIs), or the 5HT-1A partial agonist, buspirone. Problems with sedation, abuse, tolerance, dependence/ withdrawal, as well as cognitive impairment, are causes of concern with the use of benzodiazepines (Shader and Greenblatt, 1993). Issues with longer onset of symptom relief (4-6 weeks) as well as side effects including nausea, insomnia, restlessness, agitation, weight gain, and sexual side effects are associated with the use of SSRIs as anxiolytics (Davidson et al, 1999; Lydiard et al, 1996). Similarly treatment with buspirone is also characterized by a delayed onset of anxiolytic activity as well as gastrointestinal side effects (Rakel, 1990). Thus, a novel, fastacting anxiolytic, without the liabilities associated with 
current pharmacotherapies, would offer significant advantages in the treatment of anxiety-related disorders.

Previous reports have shown that the mGlu5 receptor antagonist, MPEP, has anxiolytic-like activity in a variety of conditioned and unconditioned models of anxiety (Spooren et al, 2000; Schulz et al, 2001; Tatarczynska et al, 2001; Brodkin et al, 2002a). Owing to the well-documented offtarget effects of MPEP, we wished to establish unambiguously that the observed anxiolytic effects are mediated by antagonism of mGlu5 receptors. A critical component of this process is the ability to correlate in vitro potency and in vivo occupancy of the mGlu5 receptor with in vivo efficacy in models of anxiety. This was accomplished by: (1) design and synthesis of the potent and highly selective mGlu5 receptor antagonist MTEP; (2) use of an in vivo receptor occupancy assay and (3) assessment of the anxiolytic activity of MTEP in two models of conditioned anxiety: the FPS and Geller-Seifter conflict models at doses relevant for mGlu5 receptor blockade.

MTEP is a noncompetitive mGlu5 receptor antagonist which potently blocks glutamate-induced calcium influx in recombinant cell lines expressing the human mGlu5 receptor $\left(\mathrm{IC}_{50}=5 \mathrm{nM}\right)$ and potently displaces $\left[{ }^{3} \mathrm{H}\right]$-methoxy-PEPy binding to rat cortical membranes $(\mathrm{Ki}=16 \mathrm{nM}$; Cosford et al, 2003b). Furthermore, extensive counterscreening in a wide variety of in vitro assays has shown that MTEP is highly selective and lacks any known off-target activity (Cosford et al, 2003b). Thus, MTEP was inactive in functional assays at NMDA NR2B receptors (at $>300 \mu \mathrm{M}$ ), mGlu1, mGlu2, mGlu3, or mGlu7 receptors $(10 \mu \mathrm{M})$, and was inactive in binding assays against a large panel of receptors including adenosine, adrenergic, dopamine, GABA, NMDA, AMPA, histamine, muscarinic, nicotinic, and $5 \mathrm{HT}$ receptors $(10 \mu \mathrm{M})$. Furthermore, MTEP $(100 \mu \mathrm{M})$ failed to potentiate L-AP4-induced responses in $\mathrm{CHO}_{\text {nfat }}$ cells expressing the human mGlu4 receptor (unpublished observations), while MPEP clearly potentiated this response at concentrations of $10 \mu \mathrm{M}$ and above, confirming published findings (Mathiesen et al, 2003). These data suggest that MTEP is superior to MPEP as a pharmacological tool for examining the therapeutic utility of mGlu5 receptor antagonists.

In the present study, we have used the FPS assay to explore the effects of MTEP. This model is commonly used to assess anxiety in laboratory animals (for a review, see Davis et al, 1993) and involves training animals to associate the presentation of a cue (light) with the administration of a mild foot shock. Following conditioning, startle reflex responses to brief acoustic stimuli are recorded, which are greater when acoustic stimuli are presented in the presence of the cue (light) than when presented in darkness. This elevated startle response is defined as FPS and is reduced by commonly used anxiolytics such as benzodiazepines (eg Davis, 1979) as well as mGlu5 receptor antagonists such as MPEP (Schulz et al, 2001; Brodkin et al, 2002a). In this report, both diazepam and MTEP decreased FPS with similar potencies $\left(\mathrm{ED}_{50}=0.7 \mathrm{mg} / \mathrm{kg}\right.$, i.p., and $0.9 \mathrm{mg} / \mathrm{kg}$, s.c. for MTEP and diazepam, respectively). Furthermore, MTEP was more potent at reducing FPS in the rat compared to the prototypical mGlu5 receptor antagonist MPEP $\left(\mathrm{ED}_{50}=5 \mathrm{mg} / \mathrm{kg}\right.$, i.p.; Brodkin et al, 2002a). Most importantly, there was excellent agreement between the potency of MTEP in the FPS assay and the doses of MTEP required to occupy mGlu5 receptors in brain as determined using in vivo radioligand binding (receptor occupancy $\mathrm{ED}_{50}=1 \mathrm{mg}$ / $\mathrm{kg}$, i.p.). These data suggest that efficacy in the FPS test can be detected at a dose $(1 \mathrm{mg} / \mathrm{kg}$, i.p.) giving $\sim 50 \%$ receptor occupancy and that maximal efficacy is observed at $>90 \%$ occupancy (3 mg/kg, i.p.). Given that anxiolytic-like effects are observed at doses appropriate for mGlu5 receptor occupancy in vivo, these results strongly suggest that mGlu5 receptor blockade is responsible for the behavioral effects of MTEP.

In the present study, we also examined MTEP in the Geller-Seifter conflict assay, a second 'anxiety model' commonly used to evaluate the therapeutic potential of novel compounds (eg Yasumatsu et al, 1994; Cervo et al, 2000; Brodkin et al, 2002a). In this assay, the operant task of lever pressing is rewarded with food. The animal is taught that, in the presence of a previously neutral cue (tone in this case), responding will result in food reward accompanied by a mild foot shock. Responding is recorded for both the unpunished component of the assay as well as the punished component. An anxiolytic effect of a compound is observed as an increase in the rate of responding in the punished component compared to vehicle controls. In this study, MTEP produced a 5.9-fold increase in punished responding, which was similar to the maximal response induced by diazepam (5.4-fold) and superior to that previously reported for MPEP (three-fold increase; Brodkin et al, 2002a). Furthermore, MTEP significantly increased punished responding at doses producing $>90 \%$ mGlu5 receptor occupancy, suggesting that higher receptor occupancy is required to show efficacy in this assay compared to the FPS test. Nevertheless, the effective dose range is consistent with that required to occupy mGlu5 receptors in vivo, and is also consistent with a role for mGlu5 receptors in mediating this response. While a response to stress in humans may manifest itself as an acute syndrome, such as panic attack, anxiety is a chronic condition that often requires continued pharmacological treatment. We therefore explored the efficacy of MTEP in the conflict assay after multiple treatments at the minimally effective dose of $3 \mathrm{mg} / \mathrm{kg}$. After 3 days of MTEP administration, the degree of punished responding was diminished such that there was no significant difference between the punished responding on day 5 and the vehicle treatment on day 1 . These results appear to contradict the observations of other researchers in which tolerance to an mGlu5 receptor antagonist (MPEP) was not observed in anxiety and depression assays after repeated administration (Pilc et al, 2002). Pilc et al (2002) utilized MPEP in the Vogel conflict assay at a dose that produces approximately 35\% receptor occupancy. In the conflict studies reported here, a dose of MTEP occupying $>90 \%$ of the mGlu5 receptors was administered. This considerably increased level of receptor occupancy combined with the higher specificity of MTEP compared with MPEP may explain the differing results we observed. This tolerance does not appear to be due to changes in either pharmacokinetics or receptor occupancy as repeated dosing with MTEP at $3 \mathrm{mg} / \mathrm{kg}$ did not lead to altered plasma levels nor a reduction in receptor occupancy levels compared with acute dosing (unpublished observations). Furthermore, repeated administration of the mGlu5 receptor antagonist 
MTEP did not alter the number nor the sensitivity of mGlu5 receptors in vitro compared to acute administration (unpublished observations). It has been previously reported that MPEP is effective in a model of Parkinson's disease following chronic but not acute administration (Breysse et al, 2002). Therefore, it remains to be seen whether tolerance is an assay-specific phenomenon of MTEP or if it will extend to other areas as well. However, these data are consistent with our observation on chronic dosing of a mGlu5 receptor antagonist from a different structural class in the rat FPS assay where tolerance was also observed (Roppe et al, in press). This highly potent and selective compound, 3-(5-pyridin-2-yl-2H-tetrazol-2-yl)benzonitrile, was dosed i.p. 60 min prior to testing in the FPS assay at $10 \mathrm{mg} / \mathrm{kg}$ for 5 consecutive days. Anxiolytic activity was reduced by approximately $50 \%$ on day 2 of testing with a complete loss of anxiolytic activity by day 4 .

A common undesirable side effect of benzodiazepines as therapeutics for anxiety is their sedative properties (Shader and Greenblatt, 1993). Sedative effects could be mistaken for anxiolysis in the FPS assay, although in this study neither diazepam nor MTEP significantly reduced the startle amplitude in the dark phase (ie when the animal is not expecting to receive a shock). Additionally, the unpunished component of the Geller-Seifter assay serves as an internal control to detect nonspecific drug effects as shown by a decrease in the rate of responding during the unpunished component. As expected, treatment with diazepam produced a clear, dose-dependent decrease in unpunished responding, which was significant at the highest dose tested $(1.7 \mathrm{mg} / \mathrm{kg})$. In the case of MTEP, a modest reduction was apparent, which was less than that seen with diazepam and only observed at a dose $(10 \mathrm{mg} / \mathrm{kg}$, i.p.) giving $100 \%$ receptor occupancy. These data might suggest that mGlu5 antagonists have a lower propensity to reduce motor performance compared to benzodiazepines, an assumption that was further examined using the rotarod test. Performance on the rotarod is adversely affected by sedative agents and is therefore often used to evaluate the motor disruptive effects of compounds, including anxiolytics (eg Hascoët and Bourin, 1997; Volke et al, 1998). As expected, given the well-documented motor impairment produced by benzodiazepines, treatment with diazepam dose-dependently reduced the time spent on the rotarod, with longlasting disruptions seen at the highest doses. Furthermore, co-administration of diazepam with a submaximal dose of ethanol markedly impaired rotarod performance consistent with the well-known ability of alcohol to potentiate the sedative/ataxic effects of benzodiazepines in humans (Maickel and Nash, 1986; Hu et al, 1987). In contrast, treatment with MTEP had no effect on rotarod performance per se and did not impair performance when combined with ethanol administration. It is notable that a dose of $30 \mathrm{mg} / \mathrm{kg}$ of MTEP was required for $100 \%$ receptor occupancy in mice, while $100 \%$ receptor occupancy can be obtained with a dose of $10 \mathrm{mg} / \mathrm{kg}$ of MTEP in rats. Anderson et al (2003) have discussed these findings in detail. In brief, mGlu5 receptors were occupied for a shorter period of time and plasma drug levels were lower in mice as compared to rats. It is postulated that this observed difference could be due to variances in absorption or metabolism of the compounds. Given that MTEP was tested at a dose producing $100 \%$
mGlu5 receptor occupancy in vivo, these results suggest that mGlu5 receptor antagonists are less likely to produce sedation and interact with ethanol compared to benzodiazepines. However, additional studies to evaluate the propensity for abuse and cognitive impairment as well as the extent of tolerance will also be important to fully explore the potential utility of mGlu5 receptor antagonists in the treatment of anxiety disorders.

\section{CONCLUSIONS}

The current study demonstrates that the novel mGlu5 receptor antagonist MTEP displays an anxiolytic profile similar to diazepam in the rat FPS and Geller-Seifter tests. Furthermore, when compared to diazepam, MTEP displays efficacy in anxiety models with no observed interaction with ethanol and a reduced propensity to induce motor impairment. In all of the assays, it was possible to unambiguously correlate efficacy with occupancy of MTEP at mGlu5 receptors in vivo. Further studies are warranted as it is unknown if the tolerance observed in these studies would extend to other assays as well as to human patients. If tolerance is found to be species specific, these data provide compelling evidence supporting the utility of mGlu5 receptor antagonists in the treatment of anxiety in humans.

\section{REFERENCES}

Anderson JJ, Bradbury MJ, Giracello DR, Chapman DF, Holtz G, Roppe J et al (2003). In vivo receptor occupancy of mGlu5 receptor antagonists using the novel radioligand $\left[{ }^{3} \mathrm{H}\right] 3-$ methoxy5-(pyridin-2-ylethynyl)pyridine). Eur J Pharmacol 473: 35-40.

Anderson JJ, Rao SP, Rowe B, Giracello DR, Holtz G, Chapman DF et al (2002). [ $\left.{ }^{3} \mathrm{H}\right]$ Methoxymethyl-3-[(2-methyl-1,3-thiazol-4yl)ethynyl]pyridine binding to metabotropic glutamate receptor subtype 5 in rodent brain: in vitro and in vivo characterization. J Pharmacol Exp Ther 303: 1044-1051.

Argyropoulos SP, Sandford JJ, Nutt DJ (2000). The psychobiology of anxiolytic drugs. Part 2. Pharmacological treatments of anxiety. Pharmacol Ther 88: 213-227.

Baude A, Nusser Z, Roberts JD, Mulvihill E, McIlhinney RA, Somogyi P (1993). The metabotropic glutamate receptor (mGluR1 alpha) is concentrated at perisynaptic membrane of neuronal subpopulations as detected by immunogold reaction. Neuron 11: 771-787.

Breysse N, Baunez C, Spooren W, Gasparini F, Amalric M (2002). Chronic but not acute treatment with a metabotropic glutamate 5 receptor antagonist reverses the akinetic deficits in a rat model of parkinsonism. J Neurosci 22: 5669-5678.

Brodkin J, Bradbury M, Busse C, Warren N, Bristow LJ, Varney MA (2002b). Reduced stress-induced hyperthermia in mGluR5 knockout mice. Eur J Neurosci 16: 2241-2244.

Brodkin J, Busse C, Sukoff SJ, Varney MA (2002a). Anxiolytic-like activity of the mGluR5 antagonist MPEP: a comparison with diazepam and buspirone. Pharmacol Biochem Behav 73: 359-366.

Cervo L, Munoz C, Bertaglia A, Samanin R (2000). Alnespirone and buspirone have anxiolytic-like effects in a conflict procedure in rats by stimulating 5-HT(1A) receptors. Behav Pharmacol 11: 153-160.

Conn PJ, Pin JP (1997). Pharmacology and functions of metabotropic glutamate receptors. Annu Rev Pharmacol Toxicol 37: 205-237.

Cosford ND, Roppe J, Tehrani L, Schweiger EJ, Seiders TJ, Chaudary A et al (2003a). [ $\left.{ }^{3} \mathrm{H}\right]$-Methoxymethyl-MTEP and $\left[{ }^{3} \mathrm{H}\right]-$ 
methoxy-PEPy: potent and selective radioligands for the metabotropic glutamate subtype 5 (mGlu5) receptor. Bioorg Med Chem Lett 13: 351-354.

Cosford ND, Tehrani L, Roppe J, Schweiger E, Smith ND, Anderson J et al (2003b). 3-[(2-Methyl-1,3-thiazol-4-yl)ethynyl]-pyridine: a potent and highly selective metabotropic glutamate subtype 5 receptor antagonist with anxiolytic activity. J Med Chem 46: 204-206.

Davidson JRT, DuPont RL, Hedges D, Haskins JT (1999). Efficacy, safety, and tolerability of venlafaxine extended release and buspirone in outpatients with generalized anxiety disorder. J Clin Psychiatry 60: 528-535.

Davis M (1979). Diazepam and flurazepam: effects on conditioned fear as measured with the potentiated startle paradigm. Psychopharmacology 62: 1-7.

Davis M, Falls WA, Campeau S, Kim M (1993). Fear-potentiated startle: a neural and pharmacological analysis. Behav Brain Res 58: 175-198.

DuPont RL, Rice DP, Miller LS, Shiraki SS, Rowland CR, Harwood HJ (1996). Economic costs of anxiety disorders. Anxiety 2: $167-172$.

Gasparini F, Lingenhohl K, Stoehr N, Flor PJ, Heinrich M, Vranesic I et al (1999). 2-Methyl-6-(phenylethynyl)-pyridine (MPEP), a potent, selective systemically active mGluR 5 receptor antagonist. Neuropharmacology 38: 1493-1503.

Hascoët M, Bourin M (1997). Anitconflict effect of alpidem as compared with the benzodiazepine alprazolam in rats. Pharmacol Biochem Behav 56: 317-324.

Hu WY, Reiffenstein RJ, Wong L (1987). Interaction between flurazepam and ethanol. Alcohol Drug Res 7: 107-117.

Ikeda SR, Lovinger DM, McCool BA, Lewis DL (1995). Heterologous expression of metabotropic glutamate receptors in adult rat sympathetic neurons: subtype-specific coupling to ion channels. Neuron 14: 1029-1038.

Levy M, Jing J, Chikvashvili D, Thornhill WB, Lotan I (1998). Activation of a metabotropic glutamate receptor and protein kinase $\mathrm{C}$ reduce the extent of inactivation of the $\mathrm{K}+$ channel Kv1.1/Kvbeta1.1 via dephosphorylation of Kv1.1. J Biol Chem 273: 6495-6502.

Lydiard RB (2000). An overview of generalized anxiety disorder: disease state-appropriate therapy. Clin Ther 22: A3-A19.

Lydiard RB, Brawman-Mintzer O, Ballenger JC (1996). Recent developments in the psychopharmacology of anxiety disorders. J Consult Clin Psychol 64: 660-668.

Maickel RP, Nash Jr JF (1986). Drug interactions with ethanol. Effects on body temperature and motor impairment. Neuropharmacology 25: 315-322.

Mathiesen JM, Svendsen N, Brauner-Osborne H, Thomsen C, Ramirez MT (2003). Positive allosteric modulation of the human metabotropic glutamate receptor 4 (hmGluR4) by SIB-1893 and MPEP. Br J Pharmacol 138: 1026-1030.

McCool BA, Pin JP, Harpold MM, Brust PF, Stauderman KA, Lovinger DM (1998). Rat group I metabotropic glutamate receptors inhibit neuronal $\mathrm{Ca} 2+$ channels via multiple signal transduction pathways in HEK 293 cells. J Neurophysiol 79: 379-391.

Petralia RS, Wang YX, Niedzielski AS, Wenthold RJ (1996). The metabotropic glutamate receptors, mGluR2 and mGluR3, show unique postsynaptic, presynaptic and glial localizations. Neuroscience 71: 949-976.
Pilc A, Kłodziñska A, Brañski P, Nowak G, Pałucha A, Szewczyk B et al (2002). Multiple MPEP administrations evoke anxiolyticand antidepressant-like effects in rats. Neuropharmacology 43: 181-187.

Rakel RE (1990). Long-term buspirone therapy for chronic anxiety: a multicenter international study to determine safety. South Med J 83: 194-198.

Romano C, Sesma MA, McDonald CT, O’Malley K, Van den Pol AN, Olney JW (1995). Distribution of metabotropic glutamate receptor mGluR5 immunoreactivity in rat brain. J Comp Neurol 355: 455-469.

Roppe J, Smith ND, Huang D, Tehrani L, Wang B, Anderson J et al (in press). The discovery of novel heteroaryl azoles that are metabotropic glutamate subtype 5 (mGlu5) receptor antagonists with anxiolytic activity. $J$ Med Chem.

Schulz B, Fendt M, Gasparini F, Lingenhöhl K, Kuhn R, Koch M (2001). The metabotropic glutamate receptor antagonist 2methyl-6-(phenylethynyl)-pyridine (MPEP) blocks fear conditioning in rats. Neuropharmacology 41: 1-7.

Shader RI, Greenblatt DJ (1993). Use of benzodiazepines in anxiety disorders. N Engl J Med 328: 1398-1405.

Shigemoto R, Kinoshita A, Wada E, Nomura S, Ohishi H, Takada $M$ et al (1997). Differential presynaptic localization of metabotropic glutamate receptor subtypes in the rat hippocampus. J Neurosci 17: 7503-7522.

Shigemoto R, Nomura S, Ohishi H, Sugihara H, Nakanishi S, Mizuno N (1993). Immunohistochemical localization of a metabotropic glutamate receptor, mGluR5, in the rat brain. Neurosci Lett 163: 53-57.

Spooren WPJM, Schoeffter P, Gasparini F, Kuhn R, Gentsch C (2002). Pharmacological and endocrinological characterisation of stress-induced hyperthermia in singly housed mice using classical and candidate anxiolytics (LY314582, MPEP and NKP608). Eur J Pharmacol 435: 161-170.

Spooren WPJM, Vassout A, Neijt HC, Kuhn R, Gasparini F, Roux S et al (2000). Anxiolytic-like effects of the prototypical metabotropic glutamate receptor 5 antagonist 2-methyl-6-(phenylethynyl)pyridine in rodents. J Pharmacol Exp Ther 295: 1267-1275.

Takahashi T, Forsythe ID, Tsujimoto T, Barnes-Davies M, Onodera K (1996). Presynaptic calcium current modulation by a metabotropic glutamate receptor. Science 274: 594-597.

Tatarczynska E, Klodzinska A, Chojnacka-Wojcik E, Palucha A, Gasparini F, Kuhn R et al (2001). Potential anxiolytic- and antidepressant-like effects of MPEP, a potent, selective and systemically active mGlu5 receptor antagonist. $\mathrm{Br} J$ Pharmacol 132: $1423-1430$

Varney MA, Cosford NDP, Jachec C, Rao SP, Sacaan A, Lin F-F et al (1999). SIB-1757 and SIB-1893: selective, non-competitive antagonists of metabotropic glutamate receptor type 5 (mGluR5). J Pharmacol Exp Ther 290: 170-181.

Volke V, Soosaar A, Kõks S, Vasar E, Männistö PT (1998). L-Argininine abolishes the anxiolytic-like effect of diazepam in the elevated plus maze in rats. Eur J Pharmacol 351: 287-290.

Yasumatsu H, Morimoto Y, Yamamoto Y, Takehara S, Fukuda T, Nakao $\mathrm{T}$ et al (1994). The pharmacological properties of Y23684, a benzodiazepine receptor partial agonist. Br J Pharmacol 111: $1170-1180$

Zhou FM, Hablitz JJ (1997). Metabotropic glutamate receptor enhancement of spontaneous IPSCs in neocortical interneurons. J Neurophysiol 78: 2287-2295. 